\title{
PROFESSIONAL TRAINING OF PRIMARY SCHOOL TEACHER TO ORGANIZE DIALOGIC LEARNING FOR STUDENTS: THEORETICAL CONTEXT
}

\author{
KATERYNA FOMIN
}

\begin{abstract}
The urgency of the problem of future primary school teacher training for dialogic learning of students taking into account modern challenges of globalization and digitalization of education is substantiated. The contradictions taking place in the practice of professional training in pedagogical universities are emphasized. The theoretical aspect of the outlined problem is highlighted. The characteristics of the content of the following concepts are given: dialogic learning, educational dialogue, dialogic communication, pedagogical communication, the teacher's communication culture, communication etiquette, etc. The components of teachers' pedagogical skills as personal and professional factors of successful organization of dialogic learning in school are presented. It is proved that the organization of dialogic learning at school requires the formation of a teacher's system of skills, namely: to organize and manage the dialogic process in learning; create a positive communicative atmosphere for the exchange of thoughts and ideas; pedagogically expedient to stimulate communication between students; apply advanced dialogic learning technologies; motivate students to create or solve educational tasks using productive dialogue; effectively use means of verbal and nonverbal communication; make emotional contact and listen to the interlocutor, etc. The strategy of communicative approach in the educational process of the pedagogical university is widespread, first of all as for humanities. The author notes that the readiness of future primary school teachers to organize a productive educational dialogue is determined not only by the level of development of communicative abilities and skills, but also other personal traits: intellectual qualities, motivation for teaching, love for children, emotional balance, empathy, tolerance, professional responsibility, high level of moral culture, readiness for innovative activity, desire for self-improvement and self-education, etc.

The author's material from the dissertation "Training of primary school teachers to organize dialogic learning" for the degree of Doctor of Philosophy (2020) is partially used in the article.
\end{abstract}

Keywords: training of a future primary school teacher, professional and pedagogical readiness, dialogic education, dialogic communication, teachers' communication culture, pedagogical ethics in communication.

\section{INTRODUCTION}

Nowadays we observe the impact of globalization and digitalization on education, and hence training. "Global education combines teaching methods from various global educational systems in order to develop global environmental security, as well as contributes to the development of global industries. Such educational initiatives give priority to global access to education, starting from the primary level and ending at the university level, enriching the learning experience that trains students 
for multinational leadership roles" [17, p. 19]. Academic mobility expands employment opportunities for young professionals in labor market in different countries, while increasing the requirements for their professional competencies. For the successful realization of educational goals, the problems of development of social and cultural awareness of young people, their social adaptation in the conditions of market relations and competitiveness, communicativeness and innovation are actual. This is especially concerning the training of future primary school teachers in the context of interdisciplinary, dialogic interaction and digital communication, and so on.

Thus, in the current conditions of integration of national education systems into the world educational space, the problem of improving the quality of teacher training for the completing of complex tasks of school practice, including updating the content and technological tools of teaching. In this context, the leading role belongs to the formation of the educational environment based on mutual understanding, democracy, humanism, partnership, tolerance. In fact, the organization of not monologic but dialogic learning of students serves as an effective means of developing the personality's communicative sphere. Therefore, the problem of preparing future primary school teachers for the organization of dialogic training of students is relevant.

The actualization of the subject field of the study increased due to a number of contradictions between:

- modern social challenges in education regarding the quality of educational services, including in the conditions of distance and mixed learning, and the ability of higher education institutions to meet them;

- necessity to use dialogic learning strategies in accordance with the requirements of the Standards / Educational Programs for primary school and the lack of teachers' readiness to solve these tasks in professional practice;

- necessity for primary school teachers' training to organize dialogic learning (including the use of digital technologies for online communication) and lack of proper scientific and methodological support of the process in higher education institutions.

The purpose of the article is to highlight the theoretical context of the problem of professional training of future primary school teachers to dialogic learning of students, in particular to substantiate the content of basic research concepts and outline components of teachers' pedagogical skills as personal and professional factors of successful dialogic learning.

\section{RESULTS AND DISCUSSION}

The outlined research problem is directly related to the organization of dialogic training of future primary school teachers, so it is worth determining the essence of this concept.

The category "dialogue" (gr. dialogos) has three main meanings: 1) a conversation between two or more people (figuratively: a literary work written in the form of a conversation; 2) a conversation, an exchange of ideas; 3) mutual negotiations; conversations [14, p. 225-226]. We will use all meanings, instead we will not limit ourselves only to "conversation between subjects of communication", but we will also emphasize the meaning of this communication, its spiritual value.

Such considering of the problem of dialogue, as proved by the analysis of philosophical and pedagogical sources, has a tradition and a sufficient level of justification (the principle of dialogic learning since ancient times: between a teacher (Socrates) and a student (Plato) [21].

Modern pedagogical science offers different contexts for the concept of "dialogic learning", but even in "Encyclopedia of Education" (Ukrainian edition), it is absent, there is only a general definition of "dialogue of cultures", which is consistently substantiated by prominent scientists: M. Bakhtin and V. Bibler. This book offers a brief notion that "learning of intercultural dialogue in school takes place in the process of studying real texts of a particular culture and in the form of creating students' compositions based on various situations of internal and intercultural dialogue, special dialogic forms of learning (lessons-dialogues, educational discussions and etc.); involvement in games and cultural 
activities; defining of a certain cross-culture task during the first year that can gradually "involve" other problems, subjects, age features, cultures in their dialogue in the following years" [8, p. 217].

In our opinion, a more successful interpretation of the concept of "dialogic learning" in functional terms is given in "Pedagogical skill" edited by Academician I. Zyazyun [30, p. 204-208]. From the context defined by him, it is not difficult to understand that the scientist-educator considered dialogic learning through the prism of dialogic communication and contact (interaction) between a teacher and a student. He noted "Pedagogical dialogue is a type of professional communication that meets the criteria of dialogue, providing a subject-subject principle of interaction between a teacher and students". Academician I. Zyazyun identified the main criteria of a dialogue, the leading among them are: 1) recognition of equality of personal positions, frankness and trust; 2 ) the teacher's dominance on the interlocutor and mutual influence of views; 3) modality of expression and personification of the message; 4) polyphony of interaction and the teacher's developmental assistance; 5) the twodimensional position of the teacher in communication [30, p. 205-208].

S. Honcharenko used the concept of "dialogue in learning", which meant a form of pedagogical interaction in the system a teacher -a student (a student - a student) in a learning situation with information exchange, mutual influence and regulated relations. The specificity of the educational dialogue is determined by the goals, conditions and circumstances of interaction [12, p. 96]. A significant number of scientists-teachers (I. Dychkivska, O. Pekhota, G. Selevko, etc.) consider dialogic learning as a modern effective educational technology that is humanistic in nature and productively contributes to the intellectual and sensory development of the child.

Professional-pedagogical communication as an ethical phenomenon requires proper training of future teachers in terms of not only interaction technology, but also moral experience, pedagogical wisdom in organizing relationships with students, parents, colleagues in the educational environment of general secondary education. According to L. Savenkova, in terms of its content and sphere of functioning, it can be professional or unprofessional. Professional-pedagogical communication is a communicative interaction of a teacher with students, parents, colleagues and is aimed at forming a favorable and effective psychological climate for learning, pedagogical optimization of communicative activity, interaction. It provides transmission of sociocultural elements from the teacher to students, helps acquiring relevant competencies, promotes the formation of value orientations during exchange of information. In contrast, unprofessional pedagogical communication creates fear, insecurity, reduces efficiency, impaired speech dynamics, unwillingness to think and act independently, alienation, persistent negative attitude towards the teacher and learning in general [22]. In linguistic sources, dialogic speech is often interpreted as a special type of speech activity, characterized by situationality, existence of two or more communicators, swiftness and immediacy of reflection of phenomena and situations of the objective world, and others. Dialogic communication is characterized by appeal, spontaneity and is two-way. Characteristic linguistic features of dialogic speech are its ellipticity, the presence of "ready" speech units and constricted forms [19, p. 185]. A. Myroshnichenko defines dialogic speaking as a process of speech interaction of two or more persons in the process of communication [18, p. 10]. Therefore, organizing students' non-monologic but dialogic training [10] serves as an important means of personal development, in particular communication skills. "Communication, from a management point of view, is the process by which people are informed and guided to achieve the best results." [4] "There is widespread debate about whether dialogue can be defined as a special form of communication with internal connections to designing knowledge and academic learning, or it is better served as an umbrella term for all human interaction." [4].

In our study, priority is given to educational dialogue.

Educational dialogue is a multifaceted teacher-student with changing roles, i.e. students' questions are alternately replaced by discussion of answers, and the teacher's function is mostly indirect, as a tutor. T. Florenska proved that educational dialogue helps to model dialogic communication during the lesson, the essence of which is to promote spiritual reflection of the student's personality [9, p. 67].

Educational dialogue is defined as a kind of communication between participants of the educational process in educational situations, while the information and semantic exchange between partners is 
carried out and their relations are regulated (L. Zazulina) [29, p. 6]. As V. Dudchenko notes: "Dialogue in the classroom is a special communicative atmosphere that helps the student to develop intellectual and emotional personality traits" [7].

The essence of dialogic learning, Yu. Pidborsky says, is that "it is the dialogue that has an interpersonal subject-subject nature, dialogue based on equality during training encourages learners to cooperate generating new ideas, opinions, views. In addition, the dialogic form of learning is more progressive than monologue, as it affects the role and emotional spheres, develops persistence, and indicates necessity for self-education" [20, p. 133].

Dialogic communication, in contrast to monologue, is focused not only on teacher's demands, but also on students' interests and needs; accumulation of potential for agreement and cooperation, freedom of discussion, transfer of knowledge and social norms as a personal experience, which requires individual thinking; desire for creativity, personal and professional growth, improvisation, willingness to search; dominance of methods and techniques aimed at organizing independent activities of individuals, the desire for objective control of students' academic achievements, individual approach and taking into account polymotivation of their behavior; personal (but not status) equality of a teacher and students, subject-subject relations between them [27, p. 378-379].

In the psychological context, the concept of "dialogic communication" is characterized by a number of interpretations: 1) the original, generic form of human communication, which determines the proper mental development of the individual; 2) a leading factor in this development that ensures the operational mechanism of internalization, resulting in external interaction in the system "person person" enters the internal plan, thereby determining the ("intersubjective" in content) "me" of the individual, his/her psychological uniqueness; 3) the principle and method of researching the personality; 4) the process developing according to its own laws and its own internal dynamics; 5) the highest level of organization of relations and communication between people, the most optimal for normal mental functioning and personal development, human self-realization; 6) more effective method of socio-pedagogical, psycho-correctional and other influences; 7) creative process of educational interaction [25, p. 6].

We consider the dialogic learning to be a way of organizing the educational process in a general secondary education institution, which is based on the joint activities of teachers and students in the context of creating and solving educational tasks with the help of constructive dialogue.

According to L. Major, M. Brugha, C. Froehlig, S. Walker, R. Higham, M. Vrikki (2018), dialogue can be defined in connection with other processes, such as communication, nonverbal interaction and discourse. There is a wide debate as for defining the dialogue as a special form of communication with internal connections, knowledge construction, and academic learning, or as an "umbrella" term for all human interactions. After all, the consideration of interconnected elements of dialogue often leads to certain difficulties in defining it in practice [15, p. 15].

The dialogic nature of communication between teachers and students provides a humanistic orientation of the educational process, helps to create appropriate conditions for personal acceptance of spiritual traditions, socio-cultural values, development of social meanings, achieving a certain level of self-esteem, and also provides the acquisition of key competencies necessary for life and selfrealization, progressive knowledge and social experience transmission, development of critical thinking, formation of cognitive structures and more.

I. Todorova and O. Shtepa distinguish the following main components of dialogic communication in the educational process: organizational and behavioral (ability and skills to organize a frank conversation with students); interpersonal-reflexive (elements of communication that provide adequate perception and understanding of students, themselves, situations, etc.); subject-reflexive (factors that provide subject, decentralized analysis of educational material and the process of its cognition) [26, p. 51-53].

Thus, dialogic learning is primarily learning aimed at solving problem tasks (Problem Based Learning). After all, in order to stimulate students to solve educational creative tasks, to discuss them actively in groups, it is necessary to create the situation in which students will be interested, and they 
will have different views on the same problem. In fact, collision of different opinions, ability to express them, support, listen to each other, analyze, draw conclusions, show tolerance and restraint will produce creation of student effective educational interaction. At the same time, effective educational dialogue is determined by the teacher's level of language culture of professional communication.

The teacher's communication activity of, according to G. Krokhmalna, is "a process of constant analysis and dynamic study, reaction to educational communication, monitoring environment, active assessment of the situation, control over the addressee's reaction, study and response to feedback, if necessary - appropriate stimulating and encouraging activities regarding the quality and quantity of the communication process" [13, p. 125]

The effectiveness of the implementation of methods of dialogic learning largely depends on the level of the teacher's communication culture, which means "a complex socio-pedagogical phenomenon consisting of several interrelated components (communicative attitudes, knowledge, communication skills, which are implemented under certain conditions and depend on external conditions and internal factors)" [2].

O. Semenog characterizes integral attributes of the teacher's communication culture, necessary for the organization of productive dialogic learning. They are "content, accuracy, logic, correctness, brevity of expressing opinions, provability, correctness and appropriateness of the use of terms, purity and stylistic proficiency" [23, p. 159].

Content, according to the scientist, involves a comprehensive disclosure of the opinion, compliance with the logical sequence, relevance and argumentation. Correctness of speech is compliance with the modern literary norms. The richness of speech is expressed in the teacher's ability to actively use language units of different structural levels. Stylistic proficiency ensures compliance with the specifics of a functional style, type of speech, purity of speech is indicated by correct normative pronunciation, absence of non-literary components, professional jargon, clericalism, word-parasites, unnecessary repetitions [23, p. 159].

According to N. Basyuk, the teacher's communication culture synthesizes the following components: knowledge of general theory of communication evolution, the history of the doctrine of pedagogical communication; knowledge of socio-cultural norms and ethics of pedagogical communication; knowledge of psychological and pedagogical patterns of effective pedagogical communication [1].

Thus, the teacher's communication culture is first a set of special communicative qualities, abilities, skills, communication experience, because of which a person is able to avoid psychological and pedagogical barriers in dialogic learning, predict the effectiveness of interpersonal and professional interaction.

In general, the teacher's communication culture is a manifestation of his/her personal reflection, interpreted by socio-cultural experience, which determines the individual identity, professional image. Communication culture serves as a stimulus for teachers to self-realization, as it mediates his/her attitude to the world, social interaction, professional self-affirmation. The peculiarities of the manifestation of communication culture are influenced by anxiety - emotional stability, flexibility rigidity, extroversion - introversion (N. Tvorogova), dialogic consciousness and reflection (L. Vygotsky), personal reflection (I. Semenov, S. Stepanov), personal meanings, motives (S Vaskovskaya), integral self-formation (V. Stolin), empathy (H. Rausch, E. Bordin), conformity (R. Cattell, P. Kline), features of self-perception of personality and consequently feelings of loneliness, differential emotions(K. Izard, V. Vilyunas, F. Vasyliuk) [3].

As shown in Fig. 1, the organization of dialogic training requires from the teacher a system of professional knowledge, skills, abilities, competencies, values, personal qualities, etc. The level of his communicative culture is also manifested in the ability to skillfully use the means of verbal and nonverbal communication in the educational process, to be tolerant, humane and at the same time demanding from their students. In fact, it is worth pointing out the ability to use not only verbal means of dialogic interaction, because the teacher's word is the most vivid and effective means of teaching and educating students during their adaptation to school life. It is equally important to learn to use 
skillfully non-verbal means of pedagogical influence, which significantly affect the effectiveness of educational dialogue, enhance or neutralize the word: facial expressions, posture, gestures, intonation, emotional stability and more.

It is worth noting that eye contact as a mandatory element of pedagogical techniques significantly strengthens the emotional background of the dialogue. After all, the interlocutor must look and see the eyes of the teacher or student, while feeling benevolence and tolerance. Under such conditions, students can memorize learning material faster, and the teacher's direct gaze allows dosing it, not to overload with unnecessary information and prevent anxiety, insecurity, and passivity in the classroom. It is also about reducing the distance between teacher and students in the educational environment, which increases its impact on the classroom. After all, dialogic learning in primary school provides not only an informative function, as a result of which students gain new knowledge, experience of cognition and creativity, but also provides partnership, development of personal qualities of students, ability to work in a team, empathize, listen to the interlocutor and together solve educational tasks.

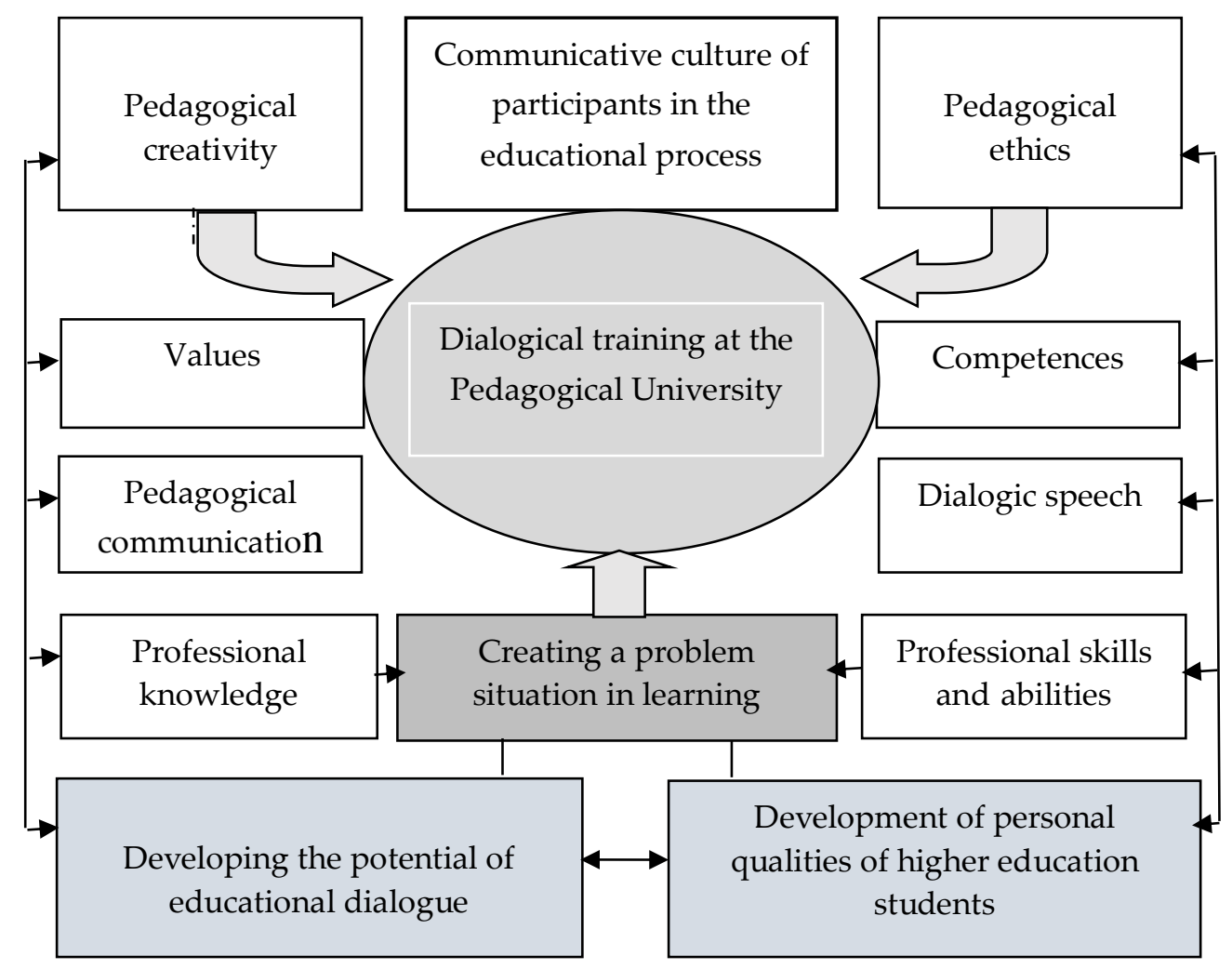

Fig. 1. Components of teachers' pedagogical skills as personal and professional factors of successful organization of dialogic learning.

The effectiveness of dialogic learning in general secondary or higher education is due to the level of culture of pedagogical communication, primarily between a teacher (teachers) and a student (students), based on compliance with general rules of conduct - etiquette [24]. The moral culture of communication is part of the culture of pedagogical communication, so an important aspect of pedagogical communication is the ethics of speech, or language etiquette. The system of rituals and appropriate verbal formulas used to establish contact and maintain a friendly tone, and is a language etiquette [28, p. 188].

We consider a somewhat broader concept of "pedagogical ethics", which combines main categories, norms, content, functions, principles of pedagogical morality; it must be guide teachers in their professional activities. It is about ethics of communication with students and their parents, ethics and professional relationships with the teaching staff, and ethics in relation to pupils with special educational needs and more. After all, the organization of dialogic learning at school and the 
preparation of future teachers for this type of activity with students presuppose, above all, high morality in relationships.

In dialogic learning, we consider the effective exchange of information as the readiness of the future teacher to organize effective communication between students and their motivation to mobilize at the psychological level. Modern scientists (H. Muhonen, H. Rasku-Puttonen, E. Pakarinen, A.-M. Poikkeus, M.-K. Lerkkanen) consider a model of forming students' knowledge in the process of educational dialogue. In fact, in their work they offer specific episodes of educational dialogues based on three main types of knowledge: facts, views and experience. Scientists pay considerable attention to the formation of students' knowledge that reflects life experience, which is the subject of dialogue [16].

At the same time, it is impossible to organize dialogic learning of children, using only theoretical knowledge in this area. A modern teacher must have a system of skills: to organize and manage the dialogic process in learning; create a positive communicative atmosphere for the exchange of thoughts and ideas; pedagogically expedient to stimulate communication between students; apply advanced dialogic learning technologies; motivate students to create or solve a problematic learning tasks through productive dialogue; effectively use means of verbal and nonverbal communication; make emotional contact and listen to the interlocutor, etc.

\section{CONCLUSIONS}

The demands of modern society and the level of development of professional and psychologicalpedagogical sciences determine the general strategy of training specialists in this field. This strategy is the application of a communicative approach in the educational process, especially in the study of foreign languages. After all, this creates conditions for mastering a foreign language, intercultural communication through the formation and development of skills of dialogic learning.

Regarding the readiness of future primary school teachers to organize a productive educational dialogue, it is worth noting the emphasis shouldn't be not only on their communicative abilities, but also on other qualities, such as: intellectual qualities, motivation for teaching, love for children, emotional balance, empathy, tolerance, professional responsibility, high level of moral culture, readiness for innovation, desire for self-improvement and self-education, etc.

In the context of forming a proper dialogue environment in an educational institution, a prominent place belongs to the skill of pedagogical communication. After all the "wrong teachers' communication creates fear, uncertainty, weakening of attention, memory, activity, breach speech dynamics and, consequently, the appearance of pupils' stereotypical expressions, meaning they reduced desire and ability to think independently, increasing conformity in behavior.

As a result, pupils gain a persistent negative attitude towards the teacher, and then towards the subject. Thus, it is due to effective pedagogical communication that a favorable atmosphere is created for positive changes in the teacher's personality; development of student's personality, mastering knowledge and skills necessary for becoming a future specialist" [11, p. 71], a space for cooperation and co-creation.

In the course of the experimental research, educational and methodological tools were developed and tested to improve the effectiveness of training of future teachers in the investigated aspect. The author's model of this preparation foresee: the gradual focus of the content of higher pedagogical education on the development of pedagogical communication skills, professional reflection by means of introduction of dialogic methods used in the process of teaching pedagogical and professionalmethodical disciplines; establishment of subject-subjective interaction among participants in the educational process, creation of the atmosphere of creativity; designing of educational dialogic environment; practice-oriented approach to disciplines included in the training curriculum of future professionals. It is proved that learning through dialogue results in not only gaining content knowledge, but also improved cogitative skills, students' ability to acquire new knowledge by researching, better communication and cooperative skills used in the learning process [6]. 


\section{REFERENCES}

[1] Basiuk N.A. Communicative culture of a high school teacher as the main aspect of pedagogical communication. Master of Nursing: Ukrainian scientific-practical journal, 11 (2014), 51-56. Available at: http://eprints.zu.edu.ua/20252/1/Basjuk1.pdf. (in Ukrainian)

[2] Bastun M.V. Modeling the educational environment in the context of intercultural dialogue. Available at: http://lib.iitta.gov.ua/7272/1/Bastun_9.pdf. (in Ukrainian)

[3] Bilonozhko A.V. Socio-psychological factors of formation of communicative culture of the future lawyer in the process of professional training: author's ref.of dis.of Cand. psychol. science; 19.00.05 social psychology; psychology of social work. Kyiv, 2008. (in Ukrainian)

[4] Bucăţa G., Rizescu A.M. The Role of Communication in Enhancing Work Effectiveness of an Organization. Land Forces Academy Review, 22 (1) (85) (2017), 49-57. doi: 10.1515/raft-2017-0008

[5] Budnyk O. Motivation of Students to the Professional Pedagogical Activities. Scientific Bulletin of Chetm, 1 (2018), 55-65. Available at: http://yadda.icm.edu.pl/yadda/element/bwmeta1.element.desklightbe55418b-854b-4b62-9d82-75a65bd087ac.

[6] Budnyk O., Fomin K., Novoselska N., Voitovych A. Preparing Teachers to Organize Dialogic Learning of Students: Communicative Aspect. Revista Inclusiones, 7 (4) (2020), 117-129.

[7] Dudchenko V. Dialogic learning technologies. Available at: http://volodarka-nvo.org.ua/ index.php/teacher-page/school-psychologis/psychology-news-/item/612-dto.html. (in Ukrainian)

[8] Kremen V.H. (Ed.) Encyclopedia of Education. Academy of Pedagogical Sciences of Ukraine. Yurinkom Inter, Kyiv, 2008. (in Ukrainian)

[9] Florenskaia T.A. Dialogue in practical psychology. Vlados, Moscow, 2001. (in Russian)

[10] Gillies R.M. "Dialogic interactions in the cooperative classroom". International Journal of Educational Research, 76 (2016), 178-189. Available at: doi: 10.1016/j.ijer.2015.02.009

[11] Holiardyk N.A., Dyka L.L. Pedagogical communication as a factor of interaction between teachers and students in higher educational institutions. Collection of scientific works of the National Academy of State Border Guard Service of Ukraine: pedagogical and psychological sciences, 2 (71) (2014), 64-73. (in Ukrainian)

[12] Honcharenko S. Ukrainian pedagogical dictionary. Lybid, Kyiv, 1997. (in Ukrainian)

[13] Krokhmalna H.I. Pedagogical communication as an academic discipline: analytical and pragmatic dimensions. In: Machynska N. (Ed.) Actual problems of pedagogical education: socio-cultural dimension: collective monograph. LNU imeni Ivana Franka, Lviv, 2018. (in Ukrainian)

[14] Busel V.T. (Ed.) Large explanatory dictionary of the modern Ukrainian language. VTF "Perun", Irpin, Kyiv, 2002. (in Ukrainian)

[15] Major L., Brugha M., Froehlig C., Walker S., Higham R., Vrikki M.A Dialogue About Educational Dialogue: Reflections on the Field and the Work of The Cambridge Educational Dialogue Research (CEDiR) Group, 2018, $15 . \quad$ Available at: http://www.academia.edu/37916282/ A_Dialogue_About_Educational_Dialogue_Reflections_on_the_Field_and_the_Work_of_The_Cambrid ge_Educational_Dialogue_Research_CEDiR_Group.

[16] Muhonen H., Rasku-Puttonen H., Pakarinen E., Poikkeus A.-M., Lerkkanen M.-K. Knowledge-building patterns in educational dialogue. International Journal of Educational Research, 81 (2017), 25-37. doi: 10.1016/j.ijer.2016.10.005

[17] Mykhats S.O., Horodyskyi T.I. Globalization's influence on the content of xxi century education as a factor of economic growth. Global and national economic problems, 19 (2017), 18-21. (in Ukrainian)

[18] Myroshnichenko A.L. Teaching speaking. Ukrainian language and literature, 31 (2004), 9-13. (in Ukrainian)

[19] Nakonechna A.O., Ordynska I.Ya. Features of teaching dialogic speech in the study of English. Collection of scientific works of the National Academy of the State Border Guard Service of Ukraine. Series: Pedagogical sciences, 2 (2015), 175-189. Available at: http://nbuv.gov.ua/UJRN/znpnadpcpn_2015_2_18. (in Ukrainian)

[20] Pidborskyi Yu.H. Application of dialogue technologies in the educational process. Bulletin of Taras Shevchenko Lviv National University, 22 (257) Part I (2012), 132-139. (In Ukrainian)

[21] Losev A.F. (Ed.) Platon. Dialogues, trans. from ancient Greek. Mysl, Moscow, 1996 (in Russian) 
[22] Savenkova L.O. Professional communication of future teachers as an object of psychological and pedagogical management: a monograph. KNEU, Kyiv, 2005. (in Ukrainian)

[23] Semenoh O. The role and place of vocabulary in the development of communicative culture of the researcher's personality. Adult education: theory, experience, prospects, collection of scientific works., 7 (2013), 159-167. (in Ukrainian)

[24] Stakhiv M.O. Ukrainian communicative etiquette, textbook. Znannia, Kyiv, 2008. (in Ukrainian)

[25] Toba M.V. Psychological determinants of dialogic pedagogical communication: author's ref. dis. ... Cand. psychol. science; 19.00 .07 - pedagogical and age psychology. Kyiv, 1999. (in Ukrainian)

[26] Todorova I.S., Shtepa O.H. The system of teacher training for pedagogical communication. Higher and secondary pedagogical education, 14 (1989), 51-56 (in Ukrainian)

[27] Vasianovych H.P. Selected works: in 5 volumes, vol. 3: Pedagogical ethics. Spolom, Lviv, 2010. (in Ukrainian)

[28] Zahnitko A.P., Danyliuk I.H. Ukrainian business language, professional and non-professional communication. TOV VKF "BAO", Donetsk, 2004. (in Ukrainian)

[29] Zazulina L.V. Dialogization of the didactic process in the course training of teachers: author's ref. dis. ... Cand. ped. Science:13.00.01. Kyiv, 2000. (in Ukrainian)

[30] Ziaziun I.A., Kramushchenko L.V., Kryvonos I.F. and oth. Pedagogical skills: textbook. Vyshcha shkola, Kyiv, 1997. (in Ukrainian)

Address: Kateryna Fomin, Vasyl Stefanyk Precarpathian National University, 57 Shevchenko St., IvanoFrankivsk 76018, Ukraine.

E-mail: kateryna.fomin@pnu.edu.ua.

Received: 29.01.2021; revised: 29.03.2021.

Фомін Катерина. Фахова підготовка вчителя початкової школи до організації діалогічного навчання учнів: теоретичний контекст. Журнал Прикарпатського університету імені Василя Стефаника, 8 (1) (2021), 80-89.

у статті обгрунтовано актуальність проблеми підготовки майбутнього вчителя початкової школи до діалогічного навчання учнів з урахуванням сучасних викдиків глобалізації та цифровізації освіти. Наголошено на суперечностях, що мають місце в практиці професійної підготовки фахівців у педагогічних університетах. Висвітлено теоретичний аспект окресленої проблеми. Подано характеристику змісту таких понять: діалогічне навчання, навчальний діалог, діалогічне спілкування, педагогічне спілкування, комунікативна культура вчителя, мовний етикет та ін. Представдено результати проєктування складових педагогічної майстерності вчителя як особистісно-професійні чинників успішної організації діалогічного навчання в школі. Доведено, що організація діалогічного навчання в школі потребуе сформованості у педагога системи умінь, а саме: організувати та управляти діалогічним процесом у навчанні; створювати позитивну комунікативну атмосферу для обміну думками, ідеями; педагогічно доцільно здійснювати стимулювання спілкування учнів; застосовувати прогресивні діалогові технології навчання; мотивувати школярів до створення чи вирішення проблемної навчальної ситуації шляхом продуктивного діалогу; ефективно використовувати засоби вербальної і невербальної комунікації; здійснювати емоційний контакт і слухати співрозмовника тощо. Пропагується стратегія комунікативного підходу в освітньому процесі педагогічного університету, передусім у вивченні дисциплін гуманітарного циклу. Автор зазначає, що готовність майбутніх учителів початкової школи до організації продуктивного навчального діалогу детермінована не лише рівнем розвитку комунікативних здібностей і вмінь, а й інших якостей особистості: інтелектуальні якості, мотивація до педагогічної діяльності, любов до дітей, емоційна 
рівновага, емпатія, толерантність, професійна відповідальність, високий рівень моральної культури, готовність до інноваційної діяльності, прагнення до самовдосконалення і самоосвіти та ін.

У статті частково використано авторські матеріали дисертаційної роботи “Підготовка вчителя початкової школи до організації діалогічного навчання” на здобуття доктора філософії (2020).

Кдючові слова: підготовка майбутнього вчителя початкової школи, професійно-педагогічна готовність, діалогічна освіта, діалогічне спілкування, комунікативна культура вчителя, педагогічна етика в спілкуванні. 